\title{
Research on the Impact of R\&D Investments on Firm Performance of Listed High-tech Enterprises
}

\author{
Zhen CUI \\ Qingdao University, Qingdao, China \\ Jian XU \& Shuqing NIE \\ Qingdao Agricultural University, Qingdao, China
}

\begin{abstract}
This paper collected the information disclosed in financial reports of 64 listed high-tech enterprises in 2013 and chose R\&D investment as the independent variable and profit margin as the dependent variable. Based on the cross-section data, this paper analyzed the impact of R\&D investments on firm performance. The results show that $R \& D$ investment has a positive impact on profit margin and the ratio of total assets to operating profit.
\end{abstract}

KEYWORD: R\&D investment; Firm performance; High-tech enterprise

\section{INTRODUCTION}

\subsection{The development of listed high-tech enterprises in China}

High-tech enterprises cover a wide range of industries, including information technology, ecommerce and e-business, biotechnology and something like that. These industries are all emerging industries with huge potential for development. Such enterprises will make great contributions to the transformation of economic development patterns and the adjustment of industrial structure. A majority of listed high-tech enterprises are in their infancy with small scale. However, their products are highly demanded in the market. Compared with traditional manufacturing enterprises, high-tech enterprises put greater emphasis on the standard R\&D management. In terms of human resources, scientific research team attracts more young and well-educated staffs and gives higher awards to the talent employees.[1] With regard to the financial management of $R \& D$ investments, the enterprises fail to make reasonable budgets for $\mathrm{R} \& \mathrm{D}$ expenditures and use the systematic and real-time supervision mechanism. Regarding the innovation, there is a huge gap between foreign and domestic high-tech enterprises. In China, the improvement in technology largely relies on the transfer of technological achievements rather than R\&D activities. [5] So it would take a longer time to bring financial benefits. In addition, corporate innovative activities often require continuous financial supports.

\subsection{The analysis of $R \& D$ investments of listed high- tech enterprises}

Currently, listed high-tech enterprises have insufficient R\&D investments. Based on the analysis of the impact of $R \& D$ investments on firm performance, scholars found that enterprises with less than 1 percent of $R \& D$ investment intensity account for a large proportion in all samples. Due to insufficient R\&D investments, the products are less likely to receive advanced technical supports. Meanwhile, some enterprises keep a higher level of R\&D investments while some still maintain a relatively lower level, and the gap tends to extend. High-tech enterprises cannot make complete financial budgets and generally use retained earnings to increase $R \& D$ investments, which eventually will lead to poor performance.[7] In addition, there is a significant difference of $R \& D$ investments at different life cycles of high-tech enterprises. At growth stage, the level of $R \& D$ investments reaches a new peak, while at maturity stage and decline stage, this level begins to decline gradually.

\section{HYPOTHESIS DEVELOPMENT}

During China's economic reform, the low-carbon economy and the knowledge economy has already become the driving force to boost Chinese economic development and the market plays a decisive role in the allocation of resources. In the market economy system, the survival and development of enterprises requires the intensive production systems and hightech products. Increasing $R \& D$ investments is an 
important source to keep the leading position and maintain sustainable development in the fierce market competition.

If the technical innovation of a high-tech company is difficult to imitate by other competitors, it could lead to competitive advantages and improve the company's core competitiveness. The impact of $\mathrm{R} \& \mathrm{D}$ investments on improving corporate competitiveness is mainly reflected in the following aspects.

Firstly, R\&D investments can result in differentiation advantage. Enterprises should make full use of $R \& D$ investments and the differentiation strategies to improve the awareness of innovation. Differentiation can enable enterprises to attract more customers.

Second, R\&D investments can reduce production costs and improve the corporate profitability. Technical innovation can ensure the profitability is higher than the average level in the same industry and create the technical barriers. Production costs are reduced in the following four aspects: (1) R\&D activities can improve the productivity. (2) The optimization of production processes reduces unnecessary expenditures. (3) R\&D activities can contribute to economies of scale. (4) The increase in R\&D investments can move down the learning curve. With the accumulation of R\&D investments, the shorter the development cycle, the less the production costs.

Finally, R\&D investments can enable the enterprises to increase market shares. In the same industry, if an enterprise can acquire core technologies, the products will dominate the market.

Based on the above analysis, we come to the following hypothesis:

Hypothesis 1: R\&D investment has a positive correlation with profit margin.

Hypothesis 2: R\&D investment has a positive impact on the ratio of total assets to operating profit.

\section{RESEARCH DESIGN}

\subsection{Data sample}

The National Twelfth Five-Year Plan put forward a scheme for the development of strategic emerging industries, including energy saving and environmental protection, new generation of information technology, biotechnology, high-end equipment manufacturing, new energy, new materials and new energy vehicles. Listed corporations should disclose information about R\&D expenditures in the financial reports. We selected 64 high-tech enterprises as the full sample and collected the related information manually from annual reports in 2013. Other financial data are from database, Wind and CSMAR database.

\subsection{Measures}

\subsubsection{Dependent variable}

The ultimate goal of $R \& D$ activities is to make profits. Profitability is an effective measurement for outside investors to evaluate firm performance. Corporate profitability is generally measured by net profit, but according to the calculation of net profit, we find that net profit is affected not only by the R\&D activities but by the other operating income and non-operating income. Therefore, profit margin is subject to measure the performance of $\mathrm{R} \& \mathrm{D}$ investments. We select profit margin and the ratio of total assets to operating profit to evaluate corporate profitability.

\subsubsection{Independent variable}

In the study of the relationship between $R \& D$ investments and firm performance, many scholars tend to choose $R \& D$ intensity and $R \& D$ personnel intensity as proxy variables.[6] However, there is no clear definition of R\&D personnel intensity. So this paper chooses R\&D intensity to measure the corporate $\mathrm{R} \& \mathrm{D}$ investments.

\subsubsection{Control variables}

Return on assets (ROA). ROA measures the performance of asset investments to make profits, which can fully reflect the input and output of the business. Based on the analysis of this variable, it is essential that enterprises raise the awareness of corporate asset management.[2] So we use ROA as a control variable to measure the impact of $\mathrm{R} \& \mathrm{D}$ investments on the profitability.

Capital expenditure ratio. High-tech enterprises belong to the capital-intensive industry. The increase in capital expenditures is an important way for enterprises to enhance the competitiveness in the future.[4] We use capital expenditure ratio to measure the impact of $R \& D$ investments on the growth capacity of high-tech enterprises.

Firm size. Some papers only use qualitative methods to evaluate firm size. According to literature review, most researchers choose the main business income and total assets as control variables. Because there is little difference between the two variables, we use the main business income as a proxy variable.

Cash flow. A company's cash flow is difficult to measure using the quantitative method. On accrual basis or cash basis, cash flow fairly reflects the company's cash receipts and payments and the operating condition. Therefore, we choose the ratio of net cash flow to total assets as a proxy variable.

Table 1 shows the definition and description of variables. 
Table 1. Variable definition.

\begin{tabular}{|l|l|l|l|}
\hline Variable type & Variable & Definition & Formula \\
\hline \multirow{3}{*}{ Dependent variable } & OPE & Profit margin & Main operating profit to the main business income \\
\cline { 2 - 4 } & AOPE & Total assets to operating profit & Total assets to the main business income \\
\hline Independent variable & RD & R\&D intensity & R\&D expenditures to operating income \\
\hline \multirow{5}{*}{ Control variable } & ROA & Return on assets & Net profit to total assets \\
\cline { 2 - 4 } & CAPEX & Capital expenditure ratio & Capital expenditures to total assets \\
\cline { 2 - 4 } & SIZE & Firm size & Logarithm of the main business income \\
\cline { 2 - 4 } & CASH & Cash flow & Net cash flow to total assets \\
\hline
\end{tabular}

\subsection{Model}

We set up valuation model like Equation 1 below.

$\mathrm{Y}=\alpha+\beta_{1} \mathrm{RD}+\beta_{2} \mathrm{ROA}+\beta_{3} \mathrm{CAPEX}+\beta_{4} \mathrm{SIZE}+$ $\beta_{5} \mathrm{CASH}+\varepsilon$

where $\mathrm{Y}$ denotes profit margin and the ratio of total assets to operating profit; $\alpha, \beta 1, \beta 2, \beta 3, \beta 4, \beta 5$ demote presumed parameters; $\varepsilon$ stands for the error term.

\section{EMPIRICAL ANALYSIS}

\subsection{Descriptive analysis}

Table 2 shows the descriptive statistics of variables.

Table 2. Descriptive statistics of variables.

\begin{tabular}{|c|c|c|c|c|}
\hline Variable & Min & Max & Mean & $\begin{array}{c}\text { Std. } \\
\text { deviation }\end{array}$ \\
\hline OPE & 0.0155 & 0.7778 & 0.29083 & 0.1549081 \\
\hline AOPE & 0.0315 & 0.6042 & 0.184509 & 0.1037755 \\
\hline RD & 0.0004 & 0.1469 & 0.016304 & 0.0224791 \\
\hline CAPEX & 18.5729 & 24.299 & 21.0798 & 0.0151285 \\
\hline SIZE & -0.1667 & 1.616 & 0.080382 & 0.1163755 \\
\hline CASH & 0.0041 & 0.2555 & 0.053146 & 0.1438492 \\
\hline
\end{tabular}

From Table 2, we can see that the maximum of OPE and AOPE is 0.7778 and 0.6042, and the minimum is 0.0155 and 0.0315 , respectively, which means that firm performance of 64 high-tech enterprises varies greatly. The mean of OPE and AOPE is 0.2908 and 0.1845 , respectively, and the two indicators reflect the low profitability in the entire industry. Mean RD is less than 0.03, indicating that $\mathrm{R} \& \mathrm{D}$ investments of high-tech enterprises are insufficient. The standard deviation of RD is less than 0.1 , which indicates that these values of $R \& D$ intensity can fairly represent the overall level of the entire industry.

\subsection{Regression analysis}

\subsection{1 $R \& D$ investment and profit margin}

In order to validate hypothesis 1 , we have studied the correlation between $\mathrm{R} \& \mathrm{D}$ investments and profit margin, the results are in Table 3.

Table 3. Regression results.

\begin{tabular}{|c|c|c|c|c|c|}
\hline Variable & Beta & $\begin{array}{c}\text { Std. } \\
\text { deviation }\end{array}$ & $\mathrm{t}$ & Sig. & $\mathrm{VIF}$ \\
\hline Constant & 6.200 & 5.103 & 1.237 & 0.218 & \\
\hline RD & 0.326 & 0.040 & $1.322^{* * *}$ & 0.001 & 1.035 \\
\hline ROA & 3.367 & 7.307 & $8.726^{* * *}$ & 0.000 & 1.104 \\
\hline CAPEX & 2.681 & 2.338 & 1.147 & 0.253 & 1.055 \\
\hline SIZE & -0.620 & 0.366 & $-1.695^{*}$ & 0.092 & 1.074 \\
\hline CASH & 6.248 & 6.935 & 0.901 & 0.369 & 1.095 \\
\hline
\end{tabular}

* shows the $10 \%$ of significance, ${ }^{* *}$ shows the $5 \%$ of significance, **** shows the $1 \%$ of significance, Adjusted $\mathrm{R}^{2}=0.700, \mathrm{~F}=26.904$, Sig. $=0.040$.

From Table 3, we can find that ROA with higher beta coefficient (3.367) than RD is more significant in improving corporate profits. In addition, there is a significant positive correlation between $R \& D$ investments and firm performance. This implies that the increase in $R \& D$ investments can promote corporate profitability. Hypothesis 1 has been verified.

\subsection{2 $R \& D$ investment and the ratio of total assets to operating profit}

In order to validate hypothesis 2 , we have to analyze the regression results in Table 4.

Table 4. Regression results.

\begin{tabular}{|c|c|c|c|c|c|}
\hline Variable & Beta & $\begin{array}{c}\text { Std. } \\
\text { deviation }\end{array}$ & $\mathrm{t}$ & Sig. & VIF \\
\hline Constant & 0.002 & 0.019 & 0.111 & 0.911 & \\
\hline RD & 0.277 & 0.050 & $4.524^{* * *}$ & 0.000 & 1.035 \\
\hline ROA & 1.215 & 0.028 & $4.341^{* * *}$ & 0.000 & 1.104 \\
\hline CAPEX & -0.002 & 0.009 & -0.247 & 0.805 & 1.055 \\
\hline SIZE & 0.003 & 0.001 & 0.072 & 0.943 & 1.074 \\
\hline CASH & 0.022 & 0.027 & 0.842 & 0.401 & 1.095 \\
\hline
\end{tabular}

" shows the $10 \%$ of significance, ${ }^{* *}$ shows the $5 \%$ of significance, **** shows the $1 \%$ of significance, Adjusted $\mathrm{R}^{2}=0.915, \mathrm{~F}=41.089$, Sig. $=0.030$.

Table 4 shows that in this study ROA has a higher beta coefficient (1.215) than RD. Both factors have a significantly positive relationship as the significance 
value for both is below 0.01 . These two can be included in the equation of regression. Hypothesis 2 has been verified.

\section{IMPLICATIONS FOR MANAGEMENT}

From the results of this study, we can derive the following important managerial implications for managerial practitioners.

\subsection{Continuously promote the reform of enterprise system}

The reform of enterprise system has made great achievements. However, there are still some enterprises with unsystematic property rights. The top management only focuses on short-term benefits and does not realize the importance of $R \& D$ investments, which is detrimental to the survival of the enterprise. Therefore, enterprise should continue to promote the reform of enterprise system and optimize the management system and operation mechanism.

\subsection{Strengthen capital accumulation management and increase $R \& D$ investments}

In the modern market economy, enterprises have become independent entities. Some scholars found that $R \& D$ expenditures mainly come from corporate retained earnings. Although the macroeconomic policies provide corporate innovation with a series of tax incentives, the enterprises should abandon the traditional modes in the planned economy era and pursue the development mode of self-reliance.[3] On the one hand, enterprises should expand financing channels and make efforts to improve the revenues; on the other hand, enterprises also need to strengthen cost management and increase the capital and $\mathrm{R} \& \mathrm{D}$ investments in order to minimize costs and maximize profits.

\subsection{High-tech enterprises should put emphasis on technical innovations}

First, enterprises need to focus on the prospects of R\&D activities. Enterprises can improve the profits by providing the products or services of $R \& D$ projects to customers. Research and development personnel are the most important resources of a technology enterprise, they can creatively resolve key technological problems of a technology enterprise. Moreover, compared with traditional manufacturing enterprises, high-tech enterprises have a lower proportion of tangible assets with higher liquidity. Therefore, regarding $R \& D$ investments, enterprises should take technical prospect, development potential and market competitiveness into consideration.

Second, enterprises need to focus on the transformation of technological achievements. For general enterprises, they may obtain core competitiveness by improving sales revenue and net profit. While for high-tech enterprises, the increase in net profit mainly relies on the increase in sales revenue of new products.[8] High-tech enterprises have to continuously make technical innovations and develop new products in order to obtain sustainable development.

\section{ACKNOWLEDGEMENT}

We would like to show the deepest gratitude to the anonymous reviewers and the editor of this review. Responsibility for the opinions and remaining errors is ours.

\section{REFERENCES}

[1] Anne C.J. \& Thomas J. 2011. Accounting choice and future performance: The case of $\mathrm{R} \& \mathrm{D}$ accounting in France. Journal of Accounting and Public Policy 30(2): 145-165.

[2] Cheng H.W. \& Zhang Y.H. 2010. An empirical study on the relationship between R\&D inputs and performance. Scientific Management Research 24(3): 110-113.

[3] Cheng X.K. \& Sun J. 2010. The value relevance of capitalized R\&D expenditures: Empirical evidences from China's listed companies. China Soft Science 24(6): 141150.

[4] Liang L.X. \& Zhang H.F. 2009. An empirical study on the R\&D inputs performance of high-tech enterprises. Journal of Central South University (Social Science Edition) 11(2): 232-236.

[5] Lv Z.W. \& Li J.H. 2008. Research on the R\&D spatial spillover and regional economic growth. Statistical Research 25(3): 28-34.

[6] Wyatt, A. 2008. What financial and non-financial information on intangibles is value-relevant? A review of the evidence. Accounting and Business Research 38(3): 217-256.

[7] Zhang J.J. \& Li X.C. 2009. A study on the relationship between R\&D and high-tech enterprise performance. Journal of Jiangsu University (Social Science Edition) 11(2): 73-78.

[8] Zhu W.P. \& Lun R. 2004. An empirical study on the relationship between R\&D inputs and firm performance of high-tech enterprises. Science and Technology Management Research 23(5):7-9. 